\title{
SPECIAL PHYSICAL TRAINING FOR STRENGTHENING ATHLETES' PHYSICAL FITNESS AND SPORTS ABILITY
}

\author{
TREINAMENTO FISICO ESPECIAL PARA O FORTALECIMENTO DO PREPARO FÍSICO EDA HABILIDADE \\ ESPORTIVA DEATLETAS

\section{ENTRENAMIENTO FÍSICO ESPECIAL PARA EL FORTALECIMIENTO DE LA PREPARACIÓN FISICA Y DE LA HABILIDAD DEPORTIVA DEATLETAS}

Original Article ARTIGO ORIGINAL Artículo Original

\begin{abstract}
Zhenpeng Huang 1 (iD
(Physical Education Professional)

Juanhua Shi ${ }^{2}$ (D)

(Physical Education Professional)

Chaohu He3 (D)

(Physical Education Professional)

1. School of Physical Education, Hanshan Normal University, Chaozhou, Guangdong, China. 2. College of Sports and Leisure, Guangdong Ocean University, Zhanjiang, Guangdong, China. 3.School of Physical Education, Kunming University, Kunming City, Yunnan, China.
\end{abstract}

\section{Correspondence}

Juanhua Shi

Zhanjiang, 524088, Guangdong, China.sjh358024980@163.com

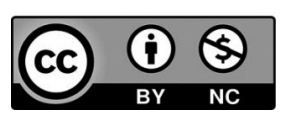

\begin{abstract}
Introduction: Special physical exercise and exceptional physical fitness are an assuredly positive combination for winning. Good exceptional physical fitness is an essential prerequisite for athletes to win competitions. Objective: This study mainly explores the relationship between the functional performance of specialized sports athletes and the performance of specific physical fitness to optimize the functional training and specific physical fitness training system of male tennis players. Methods: The article selects six tennis players as the research objects and conducts active movement monitoring and physical fitness training. Results: Athletes have poor stability in the core area and poor flexion flexibility of both hips and ankles in a symmetrical posture. There is a significant correlation between the functional movement screening test and the tennis-specific physical fitness performance test results. Conclusions: Only by studying body shape and function can we guide the diagnoses and evaluation of an athlete's physical function. We need to formulate reasonable strengthening measures based on the analysis of body shape and function. Only in this way can the athlete's body shape and physical function be effectively enhanced. Level of evidence ll; Therapeutic studies - investigation of treatment results.
\end{abstract}

Keywords: Exercise; Physical fitness; Body constitution.

\section{RESUMO}

Introdução: Exercícios físicos especiais e um preparo físico excepcional são uma combinação que garante ganhos no esporte. Um bom preparo físico éprerrequisito essencial para que atletas vençam em competições. Objetivo: Este estudo analisa principalmente a relação entre o desempenho funcional de atletas de esportes especializados e o desempenho de um preparo físico específico para otimizar o treinamento funcional e o sistema de preparo físico específico de jogadores de tênis do sexo masculino. Métodos: o estudo selecionou seis jogadores de tênis como objeto de pesquisa e conduziu monitoramento de movimentos ativo e treinamento de preparo físico. Resultados: Atletas tem baixa estabilidade na área coree pouca elasticidade de flexão no quadril e no tornozelo em uma postura simétrica. Há uma correlação importante entre o teste de rastreamento do movimento funcional e os resultados de testes de desempenho de preparo físico especificos para o tênis. Conclusões: Poderemos orientar o diagnóstico e a avaliação da função física de um atleta apenas se estudarmos a forma e a função corporal. É necessário que formulemos medidas de fortalecimento racionais com base na análise de forma e função corporal. Apenas assim a forma e a função corporal de atletas podem ser aprimoradas. Nível de evidência ll; Estudos terapêuticos - investigação de resultados de tratamento.

Descritores: Exercício; Aptidão física; Constituição corporal.

\section{RESUMEN}

Introducción: Ejercicios físicos especiales y una preparación física excepcional son una combinación de garantiza ganancias en el deporte. Una buena preparación física es un prerrequisito esencial para que atletas ganen en competiciones. Objetivo: Este estudio analiza principalmente la relación entre el rendimiento funcional de atletas de deportes especializados y el rendimiento de una preparación física especifica para optimizar el entrenamiento funcional y el sistema de preparación física específica dejugadores de tenis del sexo masculino. Métodos: El estudio seleccionó seis jugadores de tenis como objeto de investigación y condujo la supervisión activa de movimientos yentrenamiento de preparación física. Resultados: Atletas tiene baja estabilidad en el área core y poca elasticidad de flexión en el cuadril y en el tobillo en una postura simétrica. Hay una correlación importante entre la Evaluación Funcional del Movimiento y los resultados de test de rendimiento de preparación física especificos para el tenis. Conclusión: Podremos orientar el diagnostico y la evaluación de la función física de un atleta apenas siestudiamos la forma y la función corporal. Es necesario que formulemos medidas de fortalecimiento racionales con base en el análisis de forma y función corporal. Apenas de esa manera pueden primorearse la forma y la función corporal de atletas. Nivel de evidencia ll; Estudios terapéuticos - investigación de resultados de tratamiento.

Descriptores: Ejercicio; Aptitud física; Constitución corporal. 


\section{INTRODUCTION}

Tennis is a skill-led antagonistic event. The event is a ball game in which 2 or 4 people hold rackets and hit a small elastic rubber ball back and forth across the net. Tennis matches are highly antagonistic. It requires athletes to have good speed, strength, endurance, flexibility, and other physical qualities. Good exceptional physical fitness is an essential prerequisite for tennis players to win the game. For tennis players, the performance of specific physical fitness is important, but functional performance cannot be ignored either. Functional action screening (FMS test) includes a series of action pattern tests. Studies have shown that if athletes score less than 17 in the FMS test during the competition period, the probability of their lower limb's sports injury will increase by 4.7 times. If male tennis players use incorrect movement patterns to control their bodies for a long time, knee injuries will become extremely common. For this reason, this study mainly explores the relationship between the functional performance of male tennis players and the performance of specific physical fitness. ${ }^{1}$ Optimize the functional training and physical fitness training system for male tennis players to provide references for tennis players'scientific training and efficient training.

\section{METHOD}

\section{Research object}

The research object is a male tennis player of a tennis team. The number is 6 people. The sports grades are all national athletes. Age $=$ $(21.25 \pm 2.38)$ years old. Height $=(186.75 \pm 7.46) \mathrm{cm}$. Body weight $=$ $(80.75 \pm 7.07) \mathrm{kg}$. The exclusion criteria for the study subjects are as follows: the athlete has had an acute sports injury within one month before the test. Athletes who cannot participate in regular training and competitions due to long-term chronic sports injuries.

\section{Test method}

FMS test

The functional movement screening (FMS) test consists of 3 exclusion tests and seven basic movement pattern tests. The seven basic action mode tests are squat, hurdle step, front and rear split squat, shoulder flexibility, active straight knee lift, trunk stability push, and trunk rotation stability. The total test score is 21 points. ${ }^{2}$ The scoring standard is divided into four levels. That is "0-1-2-3".

The subjects completed the above seven actions as required. Do each action up to 3 times. ${ }^{3}$ On-site, a professional, will score on-site according to specific scoring standards and make records. The higher the total score, the better the functional performance of the subjects.

\section{Tennis specific physical fitness performance test}

1. 10m $\times 4$ turn-back run. We place marker buckets at the two endpoints of $10 \mathrm{~m}$. When the athlete heard the start command, he quickly sprinted forward and touched the sign bucket with his hand. Then they ran the two back and forth at the fastest speed and recorded the elapsed time. ${ }^{4}$ 2. T-type test. We put the logo bucket into a T shape. After the test started, the subjects started listening to A's command, ran to B, touched B with their right hand, and then slid to $C$. The athlete touches $C$ with his left hand and then slides to D. The athlete touches $D$ with his right hand and then slides to $B$. The athlete touches $D$ with his left hand and runs backward back to $A$.

3. Throw a solid ball with a swing forehand. The athlete prepares for a forehand and holds a $5 \mathrm{~kg}$ solid ball in both hands. Then they bend their knees and squat, turning their bodies to the right to guide the solid ball backward. Then the athlete quickly kicked his leg and turned to throw a solid ball straight ahead. We measure the point and distance of the solid ball.
Calculation of the independent variable of athlete's endurance

The article uses an artificial fish school algorithm to optimize the BP neural network's initial value weights and thresholds and then builds the athlete's endurance prediction equation. The specific steps are detailed as follows:

Assuming the count on the three-axis of $S A, C A, V A$, we use formula (1) to obtain the comprehensive count $V M_{\text {ankleo }}$ of the athlete's ankle acceleration in tennis.

$$
V M_{\text {ankleo }}=\frac{\left(S A^{2}+C A^{2}+V A^{3}\right)^{\frac{1}{2}} \cdot \varphi}{\xi_{Y}}
$$

$\xi_{y}$ represents the changes in the power, frequency, and speed indicators of the athlete during the tennis process. $\varphi$ represents the standard deviation in each indicator. We define the ankle joint acceleration comprehensive count $V M_{\text {ankleo }}$ obtained by formula (1) as an independent variable in predicting athletes' endurance. The article uses a formula (2) to extract the characteristics of the exercise load of tennis players.

$$
D=\frac{\left[\bar{y}-\bar{y}_{0}\right]}{V M_{\text {ankleo }}} \times d_{i}
$$

$\left[\bar{y}-\bar{y}_{o}\right]$ represents the average absolute error of the tennis player's endurance. $d_{i}$ represents a steady sequence of increasing endurance of tennis players. The article uses a formula (3) to obtain the relationship and closeness between adjacent variables in the athlete's endurance prediction time series.

$$
\rho(k)=\frac{\operatorname{Cov}\left(A_{t 1}, A_{t 2}\right)}{\sqrt{\operatorname{Var}\left(A_{t 1}\right) \square \sqrt{\operatorname{Var}\left(A_{t 2}\right)}}}
$$

1. $A_{t 1}, A_{t 2}$ represents the observed value of variable $\mathrm{A}$ at time $t_{1}, t_{2} . \mathrm{k}$ represents the time interval between two variables. Determine the number of hidden layers of the BP neural network represented by $\mathrm{c}$. 2. The article uses the formula (4) to define the distance between two artificial fish.

$d_{i j}=\left[\omega_{k 0}(i)-\omega_{k 0}(j)\right]+\left[\omega_{k h}(i)-\omega_{k h}(j)\right]+\left[v_{l 0}(i)-v_{l 0}(j)\right]+\left[v_{l k}(i)-v_{l k}(j)\right]$

$\omega_{k 0}$ represents the threshold of the k hidden layer neuron. $\omega_{k h}$ represents the connection weight between the $h$ input neuron and the $k$ hidden layer neuron. $v_{10}$ represents the threshold of the $l$ output neuron. $v_{l k}$ represents the connection weight between the $\mathrm{k}$ hidden layer neuron and the z output neuron.

3. Foraging behavior. Suppose $g_{i}$ represents the current state of an artificial fish. $h_{i}$ stands for food concentration. $h_{j} \leq h_{i}$ represents the food concentration of another artificial fish school in the $g_{i}$ line of sight area. The random movement of $g_{i}$ one step can use equation (5) to express the threshold learning of its next state.

$$
v_{l k}(i+1)=\frac{v_{l k}(i)+R(n)}{\rho(k) g_{i}} d_{i j}
$$

$R(n)$ represents the random number in the interval $[0, n] n$ represents the maximum step length of artificial fish movement. $v_{l k}(i)$ represents the current state threshold of $g_{i}$. 
4. Group behavior. Assume that $p_{i}$ represents the number of partners within $g_{i}$ the full line of sight. We use formula (6) to form a set.

$$
Z_{i r}=\left\{g_{i} \mid d_{i j} \leq V S\right\} \varpi_{l k}(i+1)
$$

5. Rear-end behavior. Assume that $\varphi$ represents a given artificial fish position threshold. Then we use equation (7) to calculate the state where $g_{j}$ is not crowded and has a lot of food.

$$
h_{j, \max }(i+1)=\frac{v_{l k}(i)+R(N)}{\delta h_{i}}
$$

6. We set up a bulletin board for recording the optimal state of artificial fish. We use formula (8) to construct the prediction equation of athletes' endurance.

$$
E=\frac{v_{l k}(i)+R(N)}{h_{j, \text { max }}(i+1)} \otimes Z_{i r} * v_{l k}(i+1)
$$

\section{Statistical processing}

We use SPSS20.0 software to process the data. The article makes descriptive statistics on tennis players' age, height, weight, FMS test scores, and specific physical fitness performance tests. The article uses Spearman's correlation to analyze the correlation between tennis players' FMS test scores and their specific physical fitness performance.

\section{RESULTS}

\section{Analysis of FMS Test Results and Functional Movement Abi- lity of Men's Tennis Players}

It can be seen from Table 1 that the average FMS total score of male tennis players is 16.38 points. This is 14 points above the threshold of high risk of sports injuries. This indicates that the overall level of the tennis player's functional performance is good, and the risk of sports injury is not high.

\section{Results of physical fitness tests for male tennis players}

Table 2 shows the average and standard deviation of male tennis players' seven special physical fitness performance tests. Studies have proved that coaches can use special physical fitness performance tests to determine an athlete's current competitive level and training effectiveness. ${ }^{5}$ It can become an essential basis for establishing a training effect evaluation system for certain specific sports. Forehand swing throwing, backhand swing throwing, and head swing throwing tests are the rapid power of tennis players'specific strength qualities. For tennis players, flexible and fast steps are essential. According to the needs of tennis

Table 1. Results of screening test for functional movements of male tennis players. $(\bar{x} \pm s)$.

\begin{tabular}{c|c}
\hline Number of people & $\mathbf{6}$ \\
\hline Squat test & $1.88 \pm 0.35$ \\
\hline Hurdle step test & $2.50 \pm 0.54$ \\
\hline Straight lunge squat test & $2.63 \pm 0.52$ \\
\hline Shoulder flexibility test & $2.13 \pm 0.35$ \\
\hline Active straight leg lift test & $2.62 \pm 0.52$ \\
\hline Trunk stability push-up test & $2.63 \pm 0.52$ \\
\hline Rotational stability test & $2.00 \pm 0.54$ \\
\hline Total score & $16.38 \pm 1.41$
\end{tabular}

footwork, we chose the T-shaped test and the hexagonal jump test. ${ }^{6}$ They can evaluate the agility of tennis players' footsteps from different aspects. The fan-shaped run and the $10 \mathrm{~m} \times 4$ turn-back run test combine the needs of actual tennis and competition. This is used to evaluate the fast-moving ability in the athlete's speed quality.

\section{Correlation between functional performance and specific physical fitness of male tennis players}

As shown in Table 3, there is no significant correlation between the total scores of male tennis players in the FMS test and the results of the seven special physical fitness performance tests. This shows that there is no correlation between functional motor ability and specific physical fitness performance.

Table 2. Superior physical fitness performance test results of male tennis players. $(\bar{x} \pm s)$

\begin{tabular}{c|c}
\hline Number of people & $\mathbf{6}$ \\
\hline Forehand swing throw $/ \mathrm{m}$ & $11.33 \pm 0.47$ \\
\hline Backhand swing throw/m & $11.04 \pm 0.39$ \\
\hline Head swing throwing ball/m & $8.53 \pm 0.40$ \\
\hline T type test/s & $10.54 \pm 0.79$ \\
\hline Fan run/s & $22.39 \pm 1.30$ \\
\hline $10 \mathrm{~m} \times 4$ foldback run $/ \mathrm{s}$ & $9.67 \pm 0.53$ \\
\hline Hexagon jump/s & $21.63 \pm 2.86$ \\
\hline
\end{tabular}

Table 3. Correlation between total scores of male tennis players'FMS test and specific physical fitness test.

\begin{tabular}{c|c}
\hline & FMS test total score \\
\hline Forehand swing throw/m & -0.671 \\
\hline Backhand swing throw/m & 0.338 \\
\hline Head swing throwing ball/m & -0.604 \\
\hline T type test/s & 0.012 \\
\hline Fan run/s & -0.315 \\
\hline $10 \mathrm{~m} \times 4$ foldback run/s & -0.691 \\
\hline Hexagon jump/s & -0.461 \\
\hline
\end{tabular}

\section{DISCUSSION}

During the test, the athletes made mistakes such as visibly shaking their bodies and maintaining a balance between their trunks and planks. This indicates that these athletes have limited flexibility in the hip and spine and poor reflex stability in the trunk and core parts of the body.

The shoulder flexibility test mainly evaluates the flexibility of bilateral shoulder movements. Studies have shown that the difference in muscle strength between the left and right sides of the athlete reaches $15 \%$. This is clinically diagnosed as muscle strength asymmetry and sports injury risk. ${ }^{8}$

The hurdle-over-step action mode mainly evaluates the functional compensatory action and asymmetry of the lower limbs. We combine the two action modes of hurdles and shoulder flexibility to scientifically diagnose the athlete's upper and lower limbs. ${ }^{9}$

Some wrong actions and low-scoring actions in the FMS test are specific manifestations of poor functional motor ability. ${ }^{10}$ Therefore, in sports training, coaches should attach great importance to the shortcomings and deficiencies of athletes' physical motor function capabilities, adopt appropriate strength training and flexibility exercises to prevent sports injuries, and use physical motor functions in a targeted manner. Training to improve and improve the functional performance of athletes.

\section{CONCLUSION}

Male tennis players have higher overall functional and movement capabilities. Male tennis players score relatively low in 
squats, shoulder flexibility, and rotational stability. Athletes' lower limb movement chains (hip, knee, ankle joints), shoulder, and core muscles have poor ability to perform functional movements. Coaches need to strengthen physical motor function training to improve athletes' functional movement ability while improving the athlete's specific physical fitness.

All authors declare no potential conflict of interest related to this article

AUTHORS' CONTRIBUTIONS: Each author made significant individual contributions to this manuscript. Zhenpeng Huang: writing and performing surgeries; Juanhua Shi: data analysis and performing surgeries; Chaohu He: article review and intellectual concept of the article.

\section{REFERENCES}

1. Fachrezzy F, Hermawan I, Maslikah U, Nugroho H, Sudarmanto E. Profile physical fitness athlete of slalom number water ski. International Journal of Educational Research \& Social Sciences. 2021;2(1):34-40.

2. Falaahudin A, Admaja AT, Iwandana DT. Level of physical fitness taekwondo UKM students. Quality in Sport. 2020;6(1):7-12. doi: http://dx.doi.org/10.12775/QS.2020.001.

3. Daisy S. Nutritional requirement for a healthy and successful athlete. Biotica Research Today. 2020;2(11):1149-50.

4. Henriques-Neto D, Magalhães JP, Hetherington-Rauth M, Santos DA, Baptista F, Sardinha LB. Physical fitness and bone health in young athletes and nonathletes. Sports Health. 2020;12(5):441-8. doi: http://dx.doi.org/10.1177/1941738120931755.

5. Henriques-Neto D, Minderico C, Peralta M, Marques A, Sardinha LB. Test-retest reliability of physical fitness tests among young athletes: The FITescola ${ }^{\oplus}$ battery. Clinical Physiology and Functional Imaging. 2020;40(3):173-82.
6. Coledam DHC, de Oliveira RDC. Assessment of physical fitness among non-athlete adolescents: Effect of familiarization sessions. Balt J Health Phys Act. 2020;12(4):47-57.

7. Moseid CH, Myklebust G, Slaastuen MK, Bar-Yaacov JB, Kristiansen AH, Fagerland MW, et al. The association between physical fitness level and number and severity of injury and illness in youth elite athletes. Scand J Med Sci Sports. 2019;29(11):1736-48. doi: http://dx.doi. org/10.1111/sms.13498.

8. Gani RA, Achmad IZ. Physical fitness swimming athlete in UNSIKA. Jp Jok. 2020;3(2):115-25.

9. Maslikah U, Fachrezzy F, Nugroho, H. Contribution core stability and strength to the performance athlete Slalom NumberWater Ski in terms of gender Characteristics. International Journal of Science, Technology \& Management. 2021;2(3): 908-1006. doi: https://doi.org/10.46729/ijstm.v2i3.228.

10. Paul D, Read P, Farooq A, Jones L. Factors influencing the association between coach and athlete rating of exertion: a systematic review and meta-analysis. Sports Medicine-Open. 2021;7(1):1-20. 